(c) American Dairy Science Association, 2006.

\title{
Survival Rates and Productive Herd Life of Dairy Cattle in the United States
}

\author{
E. Hare, ${ }^{1}$ H. D. Norman, ${ }^{2}$ and J. R. Wright \\ Animal Improvement Programs Laboratory, Agricultural Research Service, USDA, Beltsville, MD 20705-2350
}

\begin{abstract}
Survival rates and productive herd life were examined for 13.8 million US dairy cows that calved from January 1, 1980, through March 2, 2005. Cows that left the herd for dairy purposes or were from herds that discontinued Dairy Herd Improvement testing were excluded from any calculations to prevent underestimation of population longevity. Mean lactation length for cows without subsequently recorded lactations ranged from 205 to $235 \mathrm{~d}$ across breed-parity subsets and were 4 to $29 \mathrm{~d}$ longer for parities 2 through 7 than for parity 1. Mean survival rates were $73 \%$ to parity $2 ; 50 \%$ to parity $3 ; 32 \%$ to parity 4 ; and $19,10,5$, and $2 \%$ to parities 5 through 8 , respectively. The mean number of parities for Holsteins declined from 3.2 for those first calving in 1980 to 2.8 for those first calving in 1994 . Mean numbers of parities for other breeds first calving in 1994 were 2.9 for Ayrshires and Brown Swiss, 2.4 for Guernseys, and 3.2 for Jerseys. Breed means for productive herd life (through parity 8 ) ranged from 28 to $36 \mathrm{mo}$. All regressions of mean number of parities or mean productive herd life on year were negative. The trend for decline of many of those indicators of longevity slowed or ended after the early 1990s. Between 31 (Jersey) and 39\% (Guernsey) of herds were made up of first-calf heifers.
\end{abstract}

Key words: survival rate, herd life, culling

\section{INTRODUCTION}

Survival rates provide information about the proportion of cows that survive to each parity or for a designated period of time. Productive herd life is the length of time that individual cows remain in herds after their first calving. Those variables represent culling practices in the population, usually based on economic conditions, e.g., replacement cost, salvage value, and returns expected from various alternatives (Nieuwhof et al., 1989; VanRaden and Klaaskate, 1993; Essl, 1998).

Received November 15, 2005.

Accepted April 17, 2006.

${ }^{1}$ Current address: 57 Avery Rd., Garrison, NY 10524

${ }^{2}$ Corresponding author: dnorman@aipl.arsusda.gov
Some researchers (Nieuwhof et al., 1989; Dunklee et al., 1994; Essl, 1998) have reported a negative relationship between reproductive performance and milk production, whereas other studies (Roxström and Strandberg, 2002; Tsuruta et al., 2004) have found low correlations. The negative phenotypic correlation may result from selection for high milk yield.

Fertility is required for initiation of first lactation and is an important component of survival. VanRaden and Seykora (2003) found that daughter pregnancy rate had the highest genetic relationship with productive life of traits included in the USDA net merit index. Selection has been directed toward production traits for many decades, and accurate genetic information for most other traits is less common. An examination of herd life over time can provide information about its relationships with other economically important traits such as calving age, calving interval, production, and survival rate.

Culling rate is influenced by management style. For Wisconsin Holstein herds, Weigel et al. (2003) reported that 1) risk of involuntary culling of productive, profitable cows was lower for herds with fewer cows per employee and for which labor was provided by family members; 2) herds with fans, sprinklers, self-locking stalls, palpation racks, and maternity pens also had lower culling risks for high-yield cows; 3 ) involuntary culling was lower for $100 \%$ AI herds than for non-AI herds; and 4) operations with 3-times-daily milking and customgrown heifers had higher involuntary culling. Farms with moderately intensive grazing in the northeastern United States had lower culling rates than those with extensive grazing (Hanson et al., 1998). Seasonally calved Holsteins and Jerseys on pasture in North Carolina had lower culling rates and culling costs than did confined cows (White et al., 2002); incidences of mastitis and culling attributed to mastitis also were lower for pastured cows (Washburn et al., 2002). Clinical mastitis incidence and culling rates were not different among Dutch Holstein and Friesian herds grouped by bulk SCC, but more cows were culled for high SCC in herds with the highest SCC (Barkema et al., 1998). Samoré et al. (2003) examined the relationship between SCS and functional longevity and found that Italian Hol- 
stein-Friesian cows with the highest test-day SCS had 3 times the risk of being culled as those with the lowest SCS. Impact of mastitis on culling varied with lactation stage for Holstein herds in New York (Gröhn et al., 1997). Bascom and Young (1998) reported that culling was greater for New England cows with poor reproduction, low production, and mastitis. Culling practices often are relaxed during herd expansion (Faust et al., 2001; Weigel et al., 2003), and cows are culled for different reasons during the transition.

Type traits also impact culling. Rogers et al. (1991a) reported that final score and udder traits were positively correlated with productive life for US Jerseys. Caraviello et al. (2003) examined the relationships among type traits, inbreeding, and functional survival of US Jerseys. Cows with undesirable scores for udder depth, fore udder attachment, front teat placement, and udder support had 1.3 to 1.8 times as high a risk of being culled as those with intermediate scores. Animals with an inbreeding coefficient of $>10 \%$ had a slightly higher risk of being culled than those with a coefficient of $<5 \%$. Caraviello et al. (2004) also examined the relationship between type traits and functional survival for US Holsteins. Udder depth, fore udder attachment, udder cleft, and rear legs were related to functional longevity in all regions, but survival was highest in the Northeast and lowest in the South.

Nieuwhof et al. (1989) provided phenotypic trends in the herd life of US dairy cows with first calvings between 1966 and 1983. The purpose of the current study was to provide updated information about productive herd life and survival rates for US dairy cattle that were enrolled in DHI testing and to determine whether those longevity traits had changed since 1980.

\section{MATERIALS AND METHODS}

\section{Data}

Lactation records from the national dairy database at the Animal Improvement Programs Laboratory, USDA (Beltsville, MD), were used to determine survival rates and productive herd life for 5 US dairy breeds (Ayrshire, Brown Swiss, Guernsey, Holstein, and Jersey). Data were from 13.8 million cows in herds that participated in DHI testing. Only lactation records with calving dates between January 1, 1980, and March 2, 2005, were included. Most recent year of first calving was more restrictive and ranged from 2000 for survival to parity 2 to 1994 for survival to parity 8 . Cows were required to have remained in the same herd for all parities. In addition, the herd had to be enrolled in DHI testing for at least $1 \mathrm{yr}$ before the first calving of a cow to avoid atypical culling practices that were made based on the initial influx of information received by the herd
Table 1. Number of cows with an opportunity to calve by breed and parity

\begin{tabular}{|c|c|c|c|c|c|}
\hline Parity & Ayrshire & $\begin{array}{l}\text { Brown } \\
\text { Swiss }\end{array}$ & Guernsey & Holstein & Jersey \\
\hline 1 & 71,952 & 120,158 & 173,260 & $12,773,403$ & 654,624 \\
\hline 2 & 63,931 & 106,273 & 158,650 & $11,319,316$ & 570,973 \\
\hline 3 & 56,576 & 93,592 & 143,649 & $9,971,550$ & 494,967 \\
\hline 4 & 49,736 & 81,815 & 129,092 & $8,738,975$ & 429,201 \\
\hline 5 & 43,684 & 71,802 & 115,606 & $7,602,286$ & 372,088 \\
\hline 6 & 38,487 & 62,759 & 102,869 & $6,576,598$ & 322,992 \\
\hline 7 & 33,596 & 54,798 & 91,234 & $5,693,402$ & 279,335 \\
\hline 8 & 29,172 & 47,251 & 80,063 & $4,883,776$ & 239,510 \\
\hline
\end{tabular}

manager at the onset of testing. Age at first calving, which was calculated by subtracting birth date from earliest calving date, was restricted to 15 to $36 \mathrm{mo}$; cows with a calving age of $<18$ mo were required to have a verification code and represented only $0.01 \%$ of first-lactation cows for each breed. Calving intervals were derived from adjacent calving dates and were restricted to 270 to $650 \mathrm{~d}$ to ensure that no parities were missing. Cows were also excluded if their last record contained a termination code of 2 , which indicated that the herd had discontinued testing or that the cow was sold for dairy purposes. Because many of those cows continued to have additional records that were not available through DHI, inclusion of their incomplete lifetime information in herd means would have resulted in underestimation of population longevity.

To increase the amount of usable data, subgroups were created based on the opportunity of each cow to calve for each parity. A cow's herd was required to remain on test for an increment of $450 \mathrm{~d}$ per lactation; i.e., for a cow to be included in the opportunity group for parity 1 , the herd must have remained on test at least $450 \mathrm{~d}$ after her first calving; for parity $2,900 \mathrm{~d}$ after her first calving; for parity $3,1,350 \mathrm{~d}$; and so on. Parities after 8 were not included. This opportunity requirement was applied because life expectancy of cows in herds that terminate testing has been shown to be slightly shorter $(P<0.005)$ than that in herds that continue testing (Andrus et al., 1970). Numbers of cows within each opportunity group by breed are shown in Table 1.

\section{Methods}

Survival rates were calculated for each parity by dividing the number of cows that calved by the number of cows in the opportunity group. Survival rate for parity 1 was assumed to be $100 \%$ because information for heifers that failed to conceive was not available. Mean number of calvings by breed and year of first parity also was calculated as the sum of mean survival rates expressed 
Table 2. Numbers of cows without a subsequent lactation and their mean lactation lengths by breed and parity

\begin{tabular}{|c|c|c|c|c|c|c|}
\hline Item & Parity & Ayrshire & $\begin{array}{l}\text { Brown } \\
\text { Swiss }\end{array}$ & Guernsey & Holstein & Jersey \\
\hline \multirow[t]{7}{*}{ Cows (no.) } & 1 & 18,802 & 29,608 & 56,379 & $2,292,550$ & 109,494 \\
\hline & 2 & 14,287 & 18,809 & 37,486 & $1,972,815$ & 90,434 \\
\hline & 3 & 9,755 & 12,254 & 24,832 & $1,503,760$ & 70,875 \\
\hline & 4 & 6,530 & 8,790 & 15,605 & $1,043,882$ & 54,255 \\
\hline & 5 & 4,069 & 5,964 & 8,763 & 640,922 & 37,426 \\
\hline & 6 & 2,407 & 3,892 & 4,549 & 353,763 & 23,436 \\
\hline & 7 & 1,379 & 2,197 & 2,202 & 172,105 & 13,561 \\
\hline \multirow[t]{7}{*}{ Lactation length (d) } & 1 & 210.6 & 206.6 & 205.3 & 214.2 & 207.6 \\
\hline & 2 & 214.8 & 215.2 & 215.9 & 229.2 & 216.5 \\
\hline & 3 & 218.0 & 223.1 & 218.5 & 227.8 & 220.3 \\
\hline & 4 & 219.6 & 225.0 & 218.2 & 226.6 & 220.2 \\
\hline & 5 & 223.7 & 227.0 & 221.9 & 226.7 & 222.5 \\
\hline & 6 & 224.6 & 234.2 & 225.8 & 225.7 & 223.0 \\
\hline & 7 & 230.1 & 235.3 & 225.6 & 224.2 & 225.5 \\
\hline
\end{tabular}

in decimal form to provide another indicator of how long cows were staying in herds. Although Nieuwhof et al. (1989) found slightly higher survival rates for registered cows than for grades, a separate analysis for effect of registry status on survival was not completed because an examination of Holstein records in the national dairy database revealed a continual decline in registered cows from $50 \%$ in 1980 to $25 \%$ in 2005 .

Productive herd life was calculated with the formula of Nieuwhof et al. (1989):

$$
H=\left\{\sum_{i=1}^{7}\left[S_{i+1} C_{i}+\left(S_{i}-S_{i+1}\right) D_{i}\right]+365.25 S_{8}\right\} / 30.4375,
$$

where $H$ is the mean productive herd life in months (30.4375 d/mo), $S_{i}$ is the survival rate to parity $i$ ( $i=1$, $2, \ldots, 7), C_{i}$ is the mean calving interval in days between parities $i$ and $i+1$, and $D_{i}$ is mean DIM during parity $i$ for cows without a subsequent lactation. Mean calving intervals were those reported by Hare et al. (2006). For parity 8 , cows were assumed to have survived for $1 \mathrm{yr}$ (365.25 d) after calving, which represents DIM for parity 8 plus additional DIM for parities after 8 . Although that assumption probably underestimates actual DIM for parities $\geq 8$, some credit is provided for time opportunity in contrast to procedures in nearly all other longevity studies.

Mean herd composition by parity was computed with the formula of Nieuwhof et al. (1989):

$$
P_{i}=\left[S_{i+1} C_{i}+\left(S_{i}-S_{i+1}\right) D_{i}\right] / 30.4375 H,
$$

where $P_{i}$ is the proportion of cows in the herd with parity $i(i=1,2, \ldots, 7)$. Because all remaining cows were assumed to have survived $1 \mathrm{yr}$ after parity $8, P_{8}=$ $S_{8}(12 / H)$.

\section{RESULTS AND DISCUSSION}

Numbers of cows without a subsequent lactation and their mean lactation lengths are shown in Table 2. Mean lactation lengths for those cows ranged from 205 to $235 \mathrm{~d}$ for parities 1 through 7 and were 4 to $29 \mathrm{~d}$ longer across breed-parity subsets for parities 2 through 7 than for parity 1. Mean lactation length increased from parity 2 to 7 for all breeds except Holstein, which decreased from $229 \mathrm{~d}$ for parity 2 to $224 \mathrm{~d}$ for parity 7; the reason for this reverse trend for Holsteins is unknown. Length of time that a cow remained in the herd after last calving was 2 to $15 \mathrm{~d}$ shorter for parities 1 through 7 across breed-parity subsets than corresponding lactation lengths reported by Nieuwhof et al. (1989), except for parity 6 of Brown Swiss, which was $1 \mathrm{~d}$ longer.

Survival rates by breed and year of first calving are presented in Tables 3 through 9 for parities 2 through

Table 3. Survival rate ${ }^{1}$ to parity 2 by breed and year of first calving

\begin{tabular}{llllll}
\hline & & & & \\
Year & Ayrshire & $\begin{array}{l}\text { Brown } \\
\text { Swiss }\end{array}$ & Guernsey & Holstein & Jersey \\
\hline & & & & & \\
\cline { 2 - 5 } 1980 & 71.7 & 66.9 & 67.1 & 77.3 & 74.7 \\
1982 & 72.9 & 67.4 & 66.4 & 76.1 & 74.1 \\
1984 & 69.8 & 65.0 & 66.4 & 74.6 & 73.6 \\
1986 & 70.4 & 65.0 & 65.3 & 73.4 & 72.9 \\
1988 & 70.1 & 66.2 & 65.5 & 72.1 & 73.8 \\
1990 & 70.5 & 64.5 & 61.9 & 72.8 & 74.0 \\
1992 & 69.5 & 63.6 & 60.8 & 72.4 & 74.5 \\
1994 & 69.5 & 67.4 & 61.5 & 72.6 & 74.3 \\
1996 & 71.7 & 66.9 & 63.6 & 72.1 & 75.2 \\
1998 & 69.7 & 69.8 & 64.3 & 73.7 & 75.5 \\
2000 & 71.8 & 68.8 & 66.3 & 74.1 & 76.2 \\
Mean & 70.3 & 66.3 & 64.9 & 73.3 & 74.6 \\
\hline
\end{tabular}

${ }^{1}$ Standard errors were 0.9 to $1.3 \%$ for Ayrshires, 0.8 to $0.9 \%$ for Brown Swiss, 0.5 to $1.0 \%$ for Guernseys, $0.1 \%$ for Holsteins, and 0.3 to $0.4 \%$ for Jerseys. 
Table 4. Survival rate ${ }^{1}$ to parity 3 by breed and year of first calving

\begin{tabular}{llllll}
\hline & \multicolumn{3}{c}{ Brown } & & \\
Year & Ayrshire & Swiss & Guernsey & Holstein & Jersey \\
\hline & & & & & \\
\cline { 2 - 6 } 1980 & 50.3 & 47.4 & 44.3 & 56.6 & 56.5 \\
1982 & 49.9 & 45.6 & 43.1 & 53.6 & 54.7 \\
1984 & 49.2 & 46.9 & 44.1 & 52.8 & 54.5 \\
1986 & 48.6 & 44.3 & 42.9 & 51.2 & 54.2 \\
1988 & 47.8 & 47.1 & 42.0 & 49.9 & 55.3 \\
1990 & 48.6 & 46.2 & 38.8 & 49.7 & 54.6 \\
1992 & 47.7 & 45.2 & 37.0 & 49.2 & 55.4 \\
1994 & 46.5 & 47.0 & 37.8 & 48.9 & 55.7 \\
1996 & 50.7 & 46.1 & 39.3 & 47.6 & 55.6 \\
1998 & 49.3 & 48.4 & 40.3 & 48.5 & 56.1 \\
1999 & 50.8 & 47.3 & 41.8 & 49.0 & 56.7 \\
Mean & 48.7 & 46.2 & 41.7 & 50.3 & 55.5 \\
\hline
\end{tabular}

${ }^{1}$ Standard errors were 1.2 to $1.7 \%$ for Ayrshires, 1.1 to $1.2 \%$ for Brown Swiss, 0.7 to $1.4 \%$ for Guernseys, $0.1 \%$ for Holsteins, and 0.4 to $0.5 \%$ for Jerseys.

8, respectively. Although only survival rates for even years from 1980 and later as well as for the final year with data available are included in the tables, all years were included in the overall means. Mean survival rates for each parity (weighted by breed population of cows with an opportunity to calve for parity 1 ) were 73,50 , $32,19,10,5$, and $2 \%$ to parities 2 through 8 , respectively. Those means were lower than corresponding means of $78,57,40,27,17,10$, and $5 \%$ reported for 1966 through 1983 by Nieuwhof et al. (1989). For reported years that were same (1980 through 1983), mean survival rates for individual breeds were slightly lower than those of Nieuwhof et al. (1989) except for later parities of Holsteins. The reason for the differences is unknown but could have resulted from changes in data editing for the national database. All Holstein records in that database were examined for this study, but Nieuwhof et al. (1989) included only a population sample for Holsteins of every 15th herd.

Table 5. Survival rate ${ }^{1}$ to parity 4 by breed and year of first calving

\begin{tabular}{|c|c|c|c|c|c|}
\hline Year & Ayrshire & $\begin{array}{l}\text { Brown } \\
\text { Swiss }\end{array}$ & Guernsey & Holstein & Jersey \\
\hline & & & $-(\%)$ & & \\
\hline 1980 & 35.3 & 33.3 & 28.0 & 38.7 & 40.9 \\
\hline 1982 & 35.5 & 32.8 & 27.0 & 37.1 & 40.3 \\
\hline 1984 & 33.3 & 33.5 & 27.8 & 35.4 & 39.5 \\
\hline 1986 & 33.5 & 30.8 & 26.1 & 33.2 & 38.8 \\
\hline 1988 & 30.3 & 33.0 & 24.9 & 31.7 & 39.1 \\
\hline 1990 & 30.7 & 31.4 & 21.9 & 30.9 & 37.9 \\
\hline 1992 & 31.1 & 32.0 & 21.3 & 30.2 & 39.0 \\
\hline 1994 & 31.2 & 31.4 & 21.8 & 29.7 & 38.6 \\
\hline 1996 & 33.5 & 30.6 & 22.0 & 28.4 & 39.0 \\
\hline 1998 & 34.8 & 31.6 & 21.8 & 28.4 & 38.1 \\
\hline Mean & 32.7 & 31.9 & 25.2 & 31.8 & 39.2 \\
\hline
\end{tabular}

\footnotetext{
${ }^{1}$ Standard errors were 1.5 to $2.0 \%$ for Ayrshires, 1.2 to $1.4 \%$ for Brown Swiss, 0.9 to $1.6 \%$ for Guernseys, $0.1 \%$ for Holsteins, and 0.5 to $0.6 \%$ for Jerseys.
}

Table 6. Survival rate ${ }^{1}$ to parity 5 by breed and year of first calving

\begin{tabular}{|c|c|c|c|c|c|}
\hline Year & Ayrshire & $\begin{array}{l}\text { Brown } \\
\text { Swiss }\end{array}$ & Guernsey & Holstein & Jersey \\
\hline & & & $-(\%)$ & & \\
\hline 1980 & 23.5 & 21.8 & 16.6 & 24.2 & 27.9 \\
\hline 1982 & 22.1 & 22.8 & 16.2 & 23.3 & 27.7 \\
\hline 1984 & 21.2 & 22.1 & 16.4 & 21.6 & 26.8 \\
\hline 1986 & 22.2 & 21.0 & 13.8 & 20.0 & 25.7 \\
\hline 1988 & 18.4 & 21.9 & 13.5 & 18.4 & 25.9 \\
\hline 1990 & 18.6 & 21.2 & 11.9 & 17.4 & 24.2 \\
\hline 1992 & 19.5 & 19.9 & 11.4 & 16.6 & 25.0 \\
\hline 1994 & 19.4 & 19.6 & 11.2 & 15.8 & 24.8 \\
\hline 1996 & 21.1 & 18.0 & 11.5 & 14.7 & 24.1 \\
\hline 1997 & 20.2 & 19.3 & 12.1 & 14.3 & 25.4 \\
\hline Mean & 20.8 & 20.9 & 14.2 & 18.4 & 25.7 \\
\hline
\end{tabular}

${ }^{1}$ Standard errors were 1.7 to $2.3 \%$ for Ayrshires, 1.4 to $1.6 \%$ for Brown Swiss, 1.0 to $1.8 \%$ for Guernseys, 0.1 to $0.2 \%$ for Holsteins, and 0.6 to $0.7 \%$ for Jerseys.

For survival to parity 2 (Table 3 ), Jerseys had the highest mean survival rate ( $75 \%)$, followed by Holsteins (73\%), Ayrshires (70\%), Brown Swiss (66\%), and Guernseys $(65 \%)$. Survival to parity 2 often declined from 1980 through the mid-1990s and then began to increase slightly, although yearly fluctuations (not shown) were present, especially for the breeds with smaller populations. An earlier increase for Jersey survival may have resulted from a shift in milk pricing that gave added value to higher SNF or protein components in milk. Survival to parity 2 during 2000 was as high as or higher than survival during 1980 for Ayrshires, Brown Swiss, and Jerseys. Although Holstein survival to parity 2 has increased in recent years, Holstein survival rates were still lower during $2000(74.1 \%)$ than during $1980(77.3 \%)$. It is difficult to find comparable information in the literature about survival rate to various parities for breed populations in other countries. Any information available is usually for genetic changes, but hardly ever for phenotypic changes.

Trends for survival to parity 3 (Table 4) were similar to those for parity 2 with some yearly fluctuations (data not shown) - usually an initial decrease with improvement during more recent years. Breed ranking for survival was the same for parity 3 as for parity 2 . Approximately half of all cows with an opportunity to survive had a third calving: 49\% for Ayrshires, $46 \%$ for Brown Swiss, $42 \%$ for Guernseys, $50 \%$ for Holsteins, and $56 \%$ for Jerseys.

Survival to parity 4 (Table 5) ranged from $25 \%$ for Guernseys to $39 \%$ for Jerseys. Holsteins experienced the largest drop in survival to parity 4 from 1980 to 1998, with a decrease from 39 to $28 \%$. Guernsey survival also declined substantially from 28 to $22 \%$ during that period. The other 3 breeds had only modest survival declines of $<3 \%$. 
Table 7. Survival rate ${ }^{1}$ to parity 6 by breed and year of first calving

\begin{tabular}{|c|c|c|c|c|c|}
\hline Year & Ayrshire & $\begin{array}{l}\text { Brown } \\
\text { Swiss }\end{array}$ & Guernsey & Holstein & Jersey \\
\hline & & & $-(\%)$ & & \\
\hline 1980 & 14.7 & 13.8 & 9.9 & 14.3 & 18.4 \\
\hline 1982 & 13.6 & 15.0 & 8.6 & 13.4 & 18.0 \\
\hline 1984 & 12.8 & 13.3 & 8.4 & 12.0 & 16.8 \\
\hline 1986 & 13.7 & 13.0 & 7.4 & 10.8 & 15.3 \\
\hline 1988 & 10.8 & 13.5 & 6.6 & 9.5 & 15.6 \\
\hline 1990 & 10.4 & 12.5 & 5.7 & 8.7 & 14.9 \\
\hline 1992 & 11.9 & 12.0 & 5.8 & 8.1 & 14.7 \\
\hline 1994 & 12.0 & 11.1 & 5.5 & 7.7 & 14.7 \\
\hline 1996 & 11.9 & 9.7 & 5.2 & 6.9 & 13.8 \\
\hline Mean & 12.5 & 12.8 & 7.4 & 9.8 & 15.6 \\
\hline
\end{tabular}

${ }^{1}$ Standard errors were 1.9 to $2.5 \%$ for Ayrshires, 1.5 to $1.7 \%$ for Brown Swiss, 1.1 to $1.9 \%$ for Guernseys, 0.1 to $0.2 \%$ for Holsteins, and 0.6 to $0.8 \%$ for Jerseys.

Jerseys continued to have the largest percentage of cows that remained in the herd at advanced parities. Survival rate across all years for Jerseys was $26 \%$ to parity 5 (Table 6 ), $16 \%$ to parity 6 (Table 7 ), $9 \%$ to parity 7 (Table 8), and $5 \%$ to parity 8 (Table 9 ). Brown Swiss and Ayrshires had the same survival rates to later parities: $21 \%$ to parity $5,13 \%$ to parity $6,7 \%$ to parity 7 , and $4 \%$ to parity 8 . Corresponding survival rates for Holsteins were 18, 10,5, and $2 \%$. Across years, Guernseys had the smallest percentages (14, 7, 4, and $2 \%$ ) of cows that survived to later parities. Nieuwhof et al. (1989) found similar breed rankings for survival to later parities except that Brown Swiss had higher survival rates than Ayrshires.

Survival rate can be affected by economic factors (e.g., milk price, feed cost, and beef price), heifer inventory, and herd expansion or discontinuation. When replacements are plentiful and inexpensive, producers are less tolerant of problem animals and cull more than when replacements are scarce and expensive. Another factor that influences survival is the level of demand for specific breeds, which affects the breed population size. Culling will be reduced if demand for a specific breed is high. Since 2000 , only the Jersey breed has shown a trend for increasing numbers of cows on DHI test (Animal Improvement Programs Laboratory, 2006). Therefore, higher survival rates for Jerseys could be primarily a reflection of demand.

Mean number of parities through parity 8 (Table 10) was $<3$ for all breeds except Jersey (3.2) across years. In contrast, Nieuwhof et al. (1989) reported breed means of 3.1 to 3.5 calvings for 1966 through 1976 . Mean number of parities has declined since the 1980 s and was 2.4 for Guernseys, 2.8 for Holsteins, 2.9 for Ayrshires and Brown Swiss, and 3.2 for Jerseys that first calved during 1994. Linear regressions of mean number of parities on year of first calving (Table 10) were negative and
Table 8. Survival rate ${ }^{1}$ to parity 7 by breed and year of first calving

\begin{tabular}{|c|c|c|c|c|c|}
\hline Year & Ayrshire & $\begin{array}{l}\text { Brown } \\
\text { Swiss }\end{array}$ & Guernsey & Holstein & Jersey \\
\hline & & & & & \\
\hline 1980 & 8.7 & 8.4 & 5.0 & 7.5 & 11.4 \\
\hline 1982 & 7.5 & 8.7 & 4.2 & 6.8 & 10.5 \\
\hline 1984 & 7.3 & 8.2 & 4.1 & 6.1 & 9.8 \\
\hline 1986 & 7.5 & 6.9 & 3.6 & 5.3 & 8.6 \\
\hline 1988 & 6.4 & 7.6 & 3.4 & 4.4 & 8.7 \\
\hline 1990 & 6.4 & 7.2 & 2.9 & 3.9 & 8.6 \\
\hline 1992 & 6.7 & 6.0 & 2.6 & 3.5 & 7.7 \\
\hline 1994 & 6.6 & 6.3 & 2.5 & 3.3 & 7.9 \\
\hline 1995 & 5.3 & 5.4 & 2.5 & 3.2 & 7.5 \\
\hline Mean & 7.1 & 7.3 & 3.6 & 4.7 & 8.9 \\
\hline
\end{tabular}

${ }^{1}$ Standard errors were from 2.0 to $2.4 \%$ for Ayrshires, 1.6 to $1.8 \%$ for Brown Swiss, 1.1 to $1.8 \%$ for Guernseys, $0.2 \%$ for Holsteins, and 0.7 to $0.9 \%$ for Jerseys.

significant $(P<0.05)$ for all breeds. Declines were greatest for Holsteins and Guernseys $(-0.031$ and -0.027 parities per year, respectively). When quadratic regressions (data not shown) were compared with linear regressions, the linear coefficients produced higher $\mathrm{R}^{2}$ for all breeds except Guernseys. Linear and quadratic coefficients together were significant $(P<0.001)$ for Holsteins and Jerseys and raised the $\mathrm{R}^{2}$ considerably for Jerseys (0.73 to 0.93).

Similar declines were found for productive herd life (Table 11). A typical Holstein cow that began milking during 1994 had a productive herd life of about $32 \mathrm{mo}$ compared with $>36$ mo for a cow that began milking during 1980. However, productive herd life began to increase slightly during the most recent years for all breeds. Nieuwhof et al. (1989) found declines in productive herd life from 1966 through 1976 for all breeds except Jersey, for which productive herd life increased. Mean productive herd life across years (Table 11) was 28 mo for Guernseys; 33 mo for Ayrshires, Brown Swiss, and Holsteins; and 36 mo for Jerseys. Productive herd

Table 9. Survival rate ${ }^{1}$ to parity 8 by breed and year of first calving

\begin{tabular}{llllll}
\hline & & & & Brown \\
Year & Ayrshire & Swiss & Guernsey & Holstein & Jersey \\
\cline { 2 - 6 } & & & & & \\
\cline { 2 - 6 } 1980 & 4.4 & 4.8 & 2.5 & 3.5 & 6.4 \\
1982 & 3.9 & 4.9 & 1.7 & 3.1 & 5.7 \\
1984 & 3.9 & 4.4 & 1.8 & 2.7 & 5.1 \\
1986 & 4.0 & 4.2 & 1.5 & 2.2 & 4.4 \\
1988 & 2.9 & 3.6 & 1.4 & 1.9 & 4.4 \\
1990 & 2.9 & 3.7 & 1.2 & 1.6 & 4.6 \\
1992 & 3.4 & 3.3 & 1.0 & 1.4 & 3.8 \\
1994 & 3.4 & 2.9 & 1.1 & 1.3 & 4.0 \\
Mean & 3.7 & 3.9 & 1.6 & 2.1 & 4.7 \\
\hline
\end{tabular}

${ }^{1}$ Standard errors were from 2.1 to $2.6 \%$ for Ayrshires, 1.6 to $1.9 \%$ for Brown Swiss, 1.2 to $1.8 \%$ for Guernseys, $0.2 \%$ for Holsteins, and 0.7 to $0.9 \%$ for Jerseys. 
Table 10. Mean number of parities through parity 8 by breed and year of first calving and coefficient for linear regression of number of parities on year of first calving by breed

\begin{tabular}{llllll}
\hline & & & & \\
Year & Ayrshire & $\begin{array}{l}\text { Brown } \\
\text { Swiss }\end{array}$ & Guernsey & Holstein & Jersey \\
\hline & & & & & \\
\cline { 2 - 5 } 1980 & 3.08 & 2.96 & 2.73 & 3.22 & 3.36 \\
1981 & 3.07 & 2.97 & 2.74 & 3.17 & 3.37 \\
1982 & 3.05 & 2.97 & 2.67 & 3.13 & 3.31 \\
1983 & 3.04 & 2.88 & 2.65 & 3.08 & 3.31 \\
1984 & 2.98 & 2.93 & 2.69 & 3.05 & 3.26 \\
1985 & 2.92 & 2.86 & 2.69 & 3.00 & 3.25 \\
1986 & 3.00 & 2.85 & 2.61 & 2.96 & 3.20 \\
1987 & 2.98 & 2.88 & 2.61 & 2.92 & 3.22 \\
1988 & 2.87 & 2.93 & 2.57 & 2.88 & 3.23 \\
1989 & 2.96 & 2.96 & 2.48 & 2.85 & 3.18 \\
1990 & 2.88 & 2.87 & 2.44 & 2.85 & 3.19 \\
1991 & 2.85 & 2.81 & 2.44 & 2.83 & 3.18 \\
1992 & 2.90 & 2.82 & 2.40 & 2.81 & 3.20 \\
1993 & 2.81 & 2.81 & 2.40 & 2.80 & 3.22 \\
1994 & 2.89 & 2.86 & 2.41 & 2.79 & 3.20 \\
Mean & 2.96 & 2.89 & 2.60 & 2.94 & 3.24 \\
Linear regression coefficient & $-0.017^{* * *}$ & $-0.009^{*}$ & $-0.027^{* * *}$ & $-0.031^{* * *}$ & $-0.012^{* * *}$ \\
\hline
\end{tabular}

$* P<0.05 ; * * * P<0.001$.

life reported by Nieuwhof et al. (1989) ranged from 38 to 39 mo for all breeds except Guernsey, which had a mean productive herd life of $35 \mathrm{mo}$. They also found that mean productive herd life was 2.4 mo longer for registered Holsteins than for grades and, correspondingly, from 3.4 to 6.5 mo longer for other breeds (Ayrshire, Brown Swiss, Guernsey, and Jersey).

Linear regressions of mean productive herd life on year of first calving (Table 11) were negative for all breeds and significant $(P<0.01)$ for all breeds except Brown Swiss. Declines were greatest for Holsteins and
Guernseys ( -0.346 and $-0.301 \mathrm{mo} / \mathrm{yr}$, respectively). Linear coefficients produced a higher $\mathrm{R}^{2}$ than did quadratic coefficients for all 5 breeds. Linear and quadratic coefficients together were significant for Ayrshires $(P<$ $0.01)$ and for Holsteins and Jerseys $(P<0.001)$ and raised the $R^{2}$ substantially for Jerseys (0.42 to 0.90$)$.

Parity composition of herds (Table 12) is a reflection of the number of cows that are replaced in herds each year from both voluntary and involuntary culling. Between 31 (Jersey) and 39\% (Guernsey) of herds were made up of first-calf heifers, which was an increase

Table 11. Mean productive herd life through parity 8 by breed and year of first calving and coefficient for linear regression of productive herd life on year of first calving by breed

\begin{tabular}{llllll}
\hline & & & & \\
Year & Ayrshire & $\begin{array}{l}\text { Brown } \\
\text { Swiss }\end{array}$ & Guernsey & Holstein & Jersey \\
\cline { 2 - 4 } & & & & & \\
\cline { 2 - 5 } 1980 & 34.2 & 33.4 & 30.1 & 36.5 & 37.4 \\
1981 & 34.0 & 33.4 & 30.2 & 35.8 & 37.5 \\
1982 & 33.9 & 33.3 & 29.2 & 35.3 & 36.7 \\
1983 & 33.4 & 32.0 & 28.7 & 34.6 & 36.6 \\
1984 & 32.6 & 32.6 & 29.3 & 34.2 & 35.9 \\
1985 & 31.9 & 31.6 & 29.4 & 33.5 & 35.9 \\
1986 & 33.3 & 31.8 & 28.2 & 33.0 & 35.2 \\
1987 & 32.9 & 32.1 & 28.3 & 32.6 & 35.5 \\
1988 & 31.5 & 32.7 & 27.9 & 32.1 & 35.8 \\
1989 & 32.7 & 33.4 & 26.8 & 31.7 & 35.0 \\
1990 & 32.0 & 32.5 & 26.6 & 31.9 & 35.4 \\
1991 & 31.7 & 31.7 & 26.5 & 31.7 & 35.3 \\
1992 & 32.6 & 32.0 & 26.0 & 31.7 & 35.6 \\
1993 & 31.7 & 32.0 & 26.3 & 31.8 & 36.1 \\
1994 & 32.6 & 32.9 & 26.9 & 31.9 & 36.2 \\
Mean & 32.9 & 32.6 & 28.3 & 32.7 & 36.1 \\
Linear regression coefficient & $-0.143^{* *}$ & -0.057 & $-0.301^{* * *}$ & $-0.346^{* * *}$ & $-0.110^{* *}$ \\
\hline
\end{tabular}

$* * P<0.01 ; * * * P 0.001$. 
Table 12. Mean herd composition by parity and breed

\begin{tabular}{|c|c|c|c|c|c|c|}
\hline Parity & Ayrshire & $\begin{array}{l}\text { Brown } \\
\text { Swiss }\end{array}$ & Guernsey & Holstein & Jersey & $\begin{array}{l}\text { All } \\
\text { breeds }^{1}\end{array}$ \\
\hline & & & $(\%)$ & & & \\
\hline 1 & 34.3 & 34.1 & 39.0 & 35.4 & 31.3 & 35.2 \\
\hline 2 & 23.8 & 23.1 & 25.4 & 25.6 & 23.4 & 25.5 \\
\hline 3 & 16.4 & 16.2 & 16.1 & 17.1 & 17.1 & 17.1 \\
\hline 4 & 10.9 & 11.1 & 9.6 & 10.5 & 11.9 & 10.6 \\
\hline 5 & 6.8 & 7.2 & 5.3 & 6.0 & 7.6 & 6.1 \\
\hline 6 & 4.1 & 4.4 & 2.7 & 3.1 & 4.6 & 3.2 \\
\hline 7 & 2.3 & 2.5 & 1.3 & 1.5 & 2.6 & 1.6 \\
\hline 8 & 1.4 & 1.4 & 0.7 & 0.8 & 1.6 & 0.8 \\
\hline
\end{tabular}

${ }^{1}$ Mean weighted by breed population of cows with an opportunity to calve for parity 1 .

from the corresponding percentages of 29 (Jersey) and $33 \%$ (Guernsey) that were reported by Nieuwhof et al. (1989). Distribution of parities across breeds (weighted by breed population of cows with an opportunity to calve for parity 1; Table 1) was $35 \%$ for parity $1,26 \%$ for parity $2,17 \%$ for parity $3,11 \%$ for parity $4,6 \%$ for parity $5,3 \%$ for parity $6,2 \%$ for parity 7 , and $1 \%$ for parity 8. Nieuwhof et al. (1989) found slightly lower percentages of cows with earlier parities and slightly higher percentages of cows with later parities.

Several studies during the 1960s (Van Vleck, 1964; White and Nichols, 1965; Miller et al., 1967) showed that US dairy producers keep cows with high yield the longest, which negated the concern that high-yield 2yr-olds leave the herd earlier than those with low to moderate milk yield. Producers still want to retain high-yield cows, and the relationship between milk yield and herd life remains positive (Norman et al., 2005; Sewalem et al., 2005). Rogers et al. (1991b) reported that younger age at first calving and higher firstlactation yield resulted in a longer productive life for US Jerseys. Sewalem et al. (2005) also found that heifers older at first calving were at a higher risk of being culled than those calving at intermediate ages. They found milk yield was by far the most important factor influencing survival. In contrast, Ettema and Santos (2004) reported that Holstein culling and mortality on commercial California farms were not affected by age at first calving. A more extensive examination of the current impact on survival by phenotypic traits that are strongly influenced by environment (such as age at first calving and milk and component yields) could provide useful management information.

\section{CONCLUSIONS}

Survival rates and productive herd life of US cows were examined by breed, parity, and trend over time. Dairy cattle in the United States that first calved since 1980 averaged about 3 parities, with a productive herd life of about $2 \mathrm{yr}$ and $8 \mathrm{mo}$. Means for number of parities and productive herd life were slightly underestimated because of the exclusion of data from parities after 8 . Numbers of parities, productive herd life, and survival rates have decreased, apparently because of more intense culling primarily due to management decisions by producers rather than genetics. The trend for decline of many of those indicators of longevity slowed or ended after the early 1990s. Differences between breeds in survival and productive herd life were evident: Productive herd life was longest for Jerseys and shortest for Guernseys.

\section{ACKNOWLEDGMENTS}

The cooperation of the dairy records processing centers in supplying pedigree data for grade cows and yield data for all cows and the breed associations in supplying pedigree data for registered cows through the national Genetic Evaluation Program is acknowledged. The assistance of S. M. Hubbard, Animal Improvement Programs Laboratory (Beltsville, MD), and R. E. Pearson, Virginia Polytechnic Institute and State University (Blacksburg), in manuscript review is appreciated, as are comments and suggestions by the 2 anonymous Journal of Dairy Science reviewers, which resulted in an improved manuscript.

\section{REFERENCES}

Andrus, D. F., A. E. Freeman, and B. R. Eastwood. 1970. Age distribution and herd life expectancy in Iowa dairy herds. J. Dairy Sci. 53:764-771.

Animal Improvement Programs Laboratory. 2006. DHI participation (DHI Report K-1). http://aipl.arsusda.gov/publish/dhi/current/ partx.html Accessed Mar. 10, 2006.

Barkema, H. W., Y. H. Schukken, T. J. G. M. Lam, M. L. Beiboer, H. Wilmink, G. Benedictus, and A. Brand. 1998. Incidence of clinical mastitis in dairy herds grouped in three categories by bulk milk somatic cell counts. J. Dairy Sci. 81:411-419.

Bascom, S. S., and A. J. Young. 1998. A summary of the reasons why farmers cull cows. J. Dairy Sci. 81:2299-2305.

Caraviello, D. Z., K. A. Weigel, and D. Gianola. 2003. Analysis of the relationship between type traits, inbreeding, and functional survival in Jersey cattle using a Weibull proportional hazards model. J. Dairy Sci. 86:2984-2989.

Caraviello, D. Z., K. A. Weigel, and D. Gianola. 2004. Analysis of the relationship between type traits and functional survival in US Holstein cattle using a Weibull proportional hazards model. J. Dairy Sci. 87:2677-2686.

Dunklee, J. S., A. E. Freeman, and D. H. Kelley. 1994. Comparison of Holsteins selected for high and average milk production. 2. Health and reproductive response to selection for milk. J. Dairy Sci. 77:3683-3690.

Essl, A. 1998. Longevity in dairy cattle breeding: A review. Livest. Prod. Sci. 57:79-89.

Ettema, J. F., and J. E. P. Santos. 2004. Impact of age at calving on lactation, reproduction, health, and income in first-parity Holsteins on commercial farms. J. Dairy Sci. 87:2730-2742.

Faust, M. A., M. L. Kinsel, and M. A. Kirkpatrick. 2001. Characterizing biosecurity, health, and culling during dairy herd expansions. J. Dairy Sci. 84:955-965. 
Gröhn, Y. T., V. Ducrocq, and J. A. Hertl. 1997. Modeling the effect of a disease on culling: An illustration of the use of time-dependent covariates for survival analysis. J. Dairy Sci. 80:1755-1766.

Hanson, G. D., L. C. Cunningham, M. J. Morehart, and R. L. Parsons. 1998. Profitability of moderate intensive grazing of dairy cows in the Northeast. J. Dairy Sci. 81:821-829.

Hare, E., H. D. Norman, and J. R. Wright. 2006. Trends in calving ages and calving intervals for dairy cattle breeds in the United States. J. Dairy Sci. 89:365-370.

Miller, P., L. D. Van Vleck, and C. R. Henderson. 1967. Relationships among herd life, milk production, and calving interval. J. Dairy Sci. 50:1283-1287.

Nieuwhof, G. J., H. D. Norman, and F. N. Dickinson. 1989. Phenotypic trends in herdlife of dairy cows in the United States. J. Dairy Sci. 72:726-736.

Norman, H. D., J. L. Hutchison, M. T. Kuhn, J. R. Wright, and E. Hare. 2005. Selection intensity for yield traits, somatic cell score, and days open when culling dairy cows. J. Dairy Sci. 88(Suppl. 1):140 (Abstr. T38).

Rogers, G. W., G. L. Hargrove, J. B. Cooper, and E. P. Barton. 1991a. Relationships among survival and linear type traits in Jerseys. J. Dairy Sci. 74:286-291.

Rogers, G. W., G. L. Hargrove, J. B. Cooper, and H. D. Norman. 1991b. Management and genetic influences on survival in Jerseys. J. Dairy Sci. 74:279-285.

Roxström, A., and E. Strandberg. 2002. Genetic analysis of functional, fertility-, mastitis-, and production-determined length of productive life in Swedish dairy cattle. Livest. Prod. Sci. 74:125-135.

Samoré, A. B., M. del P. Schneider, F. Canavesi, A. Bagnato, and A. F. Groen. 2003. Relationship between somatic cell count and functional longevity assessed using survival analysis in Italian Holstein-Friesian cows. Livest. Prod. Sci. 80:211-220.
Sewalem, A., G. J. Kistemaker, V. Ducrocq, and B. J. Van Doormaal. 2005. Genetic analysis of herd life in Canadian dairy cattle on a lactation basis using a Weibull proportional hazards model. J. Dairy Sci. 88:368-375.

Tsuruta, S., I. Misztal, and T. J. Lawlor. 2004. Genetic correlations among production, body size, udder, and productive life traits over time in Holsteins. J. Dairy Sci. 87:1457-1468.

VanRaden, P. M., and E. J. H. Klaaskate. 1993. Genetic evaluation of length of productive life including predicted longevity of live cows. J. Dairy Sci. 76:2758-2764.

VanRaden, P. M., and A. J. Seykora. 2003. Net merit as a measure of lifetime profit: 2003 revision. AIPL Res. Rep. NM\$2(7-03). http:// www.aipl.arsusda.gov/reference/nmcalc.htm Accessed Feb. 14, 2006.

Van Vleck, L. D. 1964. First lactation performance and herd life. J. Dairy Sci. 47:1000-1003.

Washburn, S. P., S. L. White, J. T. Green, Jr., and G. A. Benson. 2002. Reproduction, mastitis, and body condition of seasonally calved Holstein and Jersey cows in confinement or pasture systems. J. Dairy Sci. 85:105-111.

Weigel, K. A., R. W. Palmer, and D. Z. Caraviello. 2003. Investigation of factors affecting voluntary and involuntary culling in expanding dairy herds in Wisconsin using survival analysis. J. Dairy Sci. 86:1482-1486.

White, S. L., G. A. Benson, S. P. Washburn, and J. T. Green, Jr. 2002. Milk production and economic measures in confinement or pasture systems using seasonally calved Holstein and Jersey cows. J. Dairy Sci. 85:95-104.

White, J. M., and J. R. Nichols. 1965. Relationships between first lactation, later performance, and length of herd life in HolsteinFriesian cattle. J. Dairy Sci. 48:468-474. 